\title{
SCAT5.
}

\section{SPORT CONCUSSION ASSESSMENT TOOL - 5TH EDITION}

DEVELOPED BY THE CONCUSSION IN SPORT GROUP

FOR USE BY MEDICAL PROFESSIONALS ONLY

supported by

\section{(2ii.) FIFA Юல (I) FIE}

\section{Patient details}

Name:

DOB:

Address:

ID number:

Examiner:

Date of Injury: Time:

\section{WHAT IS THE SCAT5?}

The SCAT5 is a standardized tool for evaluating concussions designed for use by physicians and licensed healthcare professionals ${ }^{1}$. The SCAT 5 cannot be performed correctly in less than 10 minutes.

If you are not a physician or licensed healthcare professional, please use the Concussion Recognition Tool 5 (CRT5). The SCAT5 is to be used for evaluating athletes aged 13 years and older. For children aged 12 years or younger, please use the Child SCAT5.

Preseason SCAT5 baseline testing can be useful for interpreting post-injury test scores, but is not required for that purpose.Detailed instructions for use of the SCAT5 are provided on page 7. Please read through these instructions carefully before testing the athlete. Brief verbal instructions for each test are given in italics. The only equipment required for the tester is a watch or timer.

This tool may be freely copied in its current form for distribution to individuals, teams, groups and organizations. It should not be altered in any way, re-branded or sold for commercial gain. Any revision, translation or reproduction in a digital form requires specific approval by the Concussion in Sport Group.

\section{Recognise and Remove}

A head impact by either a direct blow or indirect transmission of force can be associated with a serious and potentially fatal brain injury. If there are significant concerns, including any of the red flags listed in Box 1, then activation of emergency procedures and urgent transport to the nearest hospital should be arranged.
Key points

- Any athlete with suspected concussion should be REMOVED FROM PLAY, medically assessed and monitored for deterioration. No athlete diagnosed with concussion should be returned to play on the day of injury.

- If an athlete is suspected of having a concussion and medical personnel are not immediately available, the athlete should be referred to a medical facility for urgent assessment.

- Athletes with suspected concussion should not drink alcohol, use recreational drugs and should not drive a motor vehicle until cleared to do so by a medical professional.

- Concussion signs and symptoms evolve over time and it is important to consider repeat evaluation in the assessment of concussion.

- The diagnosis of a concussion is a clinical judgment, made by a medical professional. The SCAT 5 should NOT be used by itself to make, or exclude, the diagnosis of concussion. An athlete may have a concussion even if their SCAT5 is "normal".

Remember:

- The basic principles of first aid (danger, response, airway, breathing, circulation) should be followed.

- Do not attempt to move the athlete (other than that required for airway management) unless trained to do so.

- Assessment for a spinal cord injury is a critical part of the initial on-field assessment.

- Do not remove a helmet or any other equipment unless trained to do so safely. 


\section{IMMEDIATE OR ON-FIELD ASSESSMENT}

The following elements should be assessed for all athletes who are suspected of having a concussion prior to proceeding to the neurocognitive assessment and ideally should be done on-field after the first first aid / emergency care priorities are completed.

If any of the "Red Flags" or observable signs are noted after a direct or indirect blow to the head, the athlete should be immediately and safely removed from participation and evaluated by a physician or licensed healthcare professional.

Consideration of transportation to a medical facility should be at the discretion of the physician or licensed healthcare professional.

The GCS is important as a standard measure for all patients and can be done serially if necessary in the event of deterioration in conscious state. The Maddocks questions and cervical spine exam are critical steps of the immediate assessment; however, these do not need to be done serially.

\section{STEP 1: RED FLAGS}

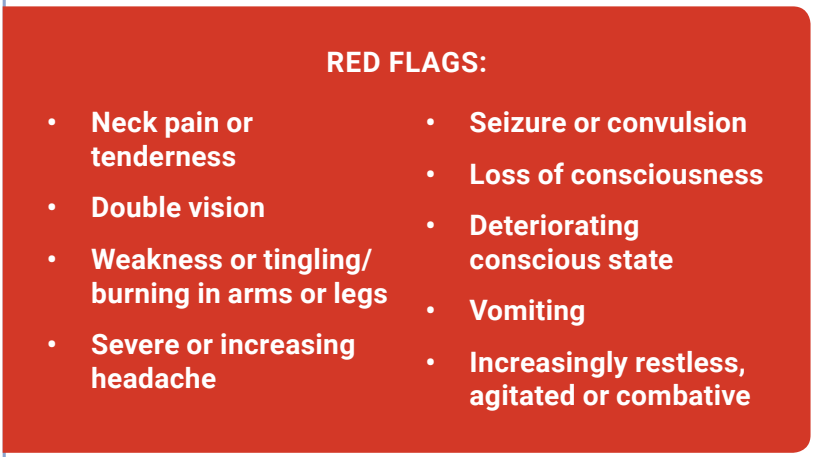

\section{STEP 2: OBSERVABLE SIGNS}

Witnessed $\square \quad$ Observed on Video $\square$

Lying motionless on the playing surface

Balance / gait difficulties / motor incoordination: stumbling, slow / laboured movements

Disorientation or confusion, or an inability to respond appropriately to questions

Blank or vacant look

Facial injury after head trauma

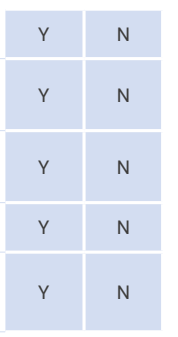

\section{STEP 3: MEMORY ASSESSMENT MADDOCKS QUESTIONS ${ }^{2}$}

"I am going to ask you a few questions, please listen carefully and give your best effort. First, tell me what happened?"
Name:

DOB:

Address:

ID number:

Examiner:

Date:

\section{STEP 4: EXAMINATION \\ GLASGOW COMA SCALE (GCS) 3}

Time of assessment

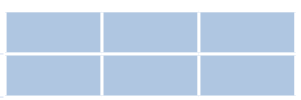

Best eye response $(\mathrm{E})$

No eye opening

Eye opening in response to pain

Eye opening to speech

Eyes opening spontaneously

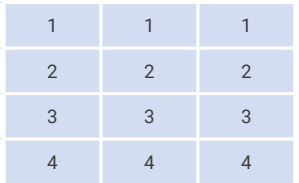

Best verbal response $(\mathrm{V})$

No verbal response

Incomprehensible sounds

Inappropriate words

Confused

Oriented

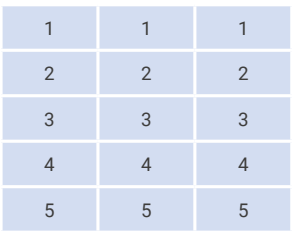

Best motor response $(\mathrm{M})$

No motor response

Extension to pain

Abnormal flexion to pain

Flexion / Withdrawal to pain

Localizes to pain

Obeys commands

Glasgow Coma score $(E+V+M)$

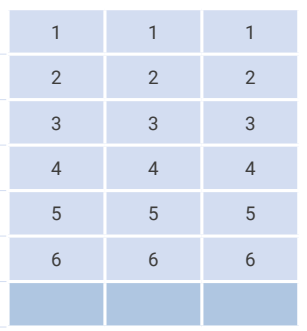

\section{CERVICAL SPINE ASSESSMENT}

Does the athlete report that their neck is pain free at rest?

If there is NO neck pain at rest, does the athlete have a full range of ACTIVE pain free movement?

Is the limb strength and sensation normal?

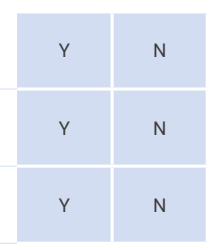

In a patient who is not lucid or fully conscious, a cervical spine injury should be assumed until proven otherwise. 
OFFICE OR OFF-FIELD ASSESSMENT

Please note that the neurocognitive assessment should be done in a distraction-free environment with the athlete in a resting state.

\section{STEP 1: ATHLETE BACKGROUND}

Sport / team / school:

Date / time of injury:

Years of education completed:

Age:

Gender: M / F / Other

Dominant hand: left / neither / right

How many diagnosed concussions has the

athlete had in the past?

When was the most recent concussion?:

How long was the recovery (time to being cleared to play)

from the most recent concussion? (days)

Has the athlete ever been:

Hospitalized for a head injury?

Diagnosed / treated for headache disorder or migraines?

Diagnosed with a learning disability / dyslexia?

Diagnosed with ADD / ADHD?

Diagnosed with depression, anxiety

or other psychiatric disorder?

\begin{tabular}{|c|c|}
\hline Yes & No \\
\hline Yes & No \\
\hline Yes & No \\
\hline Yes & No \\
\hline Yes & No \\
\hline
\end{tabular}

Current medications? If yes, please list:
Name:

DOB:

Address:

ID number:

Examiner:

Date:

\section{STEP 2: SYMPTOM EVALUATION}

The athlete should be given the symptom form and asked to read this instruction paragraph out loud then complete the symptom scale. For the baseline assessment, the athlete should rate his/her symptoms based on how he/she typically feels and for the post injury assessment the athlete should rate their symptoms at this point in time.

Please Check: $\square$ Baseline $\square$ Post-Injury

Please hand the form to the athlete

Headache

"Pressure in head"

Neck Pain

Nausea or vomiting

Dizziness

Blurred vision

Balance problems

Sensitivity to light

Sensitivity to noise

Feeling slowed down

Feeling like "in a fog"

"Don't feel right"

Difficulty concentrating

Difficulty remembering

Fatigue or low energy

Confusion

Drowsiness

More emotional

Irritability

Sadness

Nervous or Anxious

Trouble falling asleep

(if applicable)

\begin{tabular}{|c|c|c|c|c|c|c|}
\hline none & & & & & & \\
\hline 0 & 1 & 2 & 3 & 4 & 5 & 6 \\
\hline 0 & 1 & 2 & 3 & 4 & 5 & 6 \\
\hline 0 & 1 & 2 & 3 & 4 & 5 & 6 \\
\hline 0 & 1 & 2 & 3 & 4 & 5 & 6 \\
\hline 0 & 1 & 2 & 3 & 4 & 5 & 6 \\
\hline 0 & 1 & 2 & 3 & 4 & 5 & 6 \\
\hline 0 & 1 & 2 & 3 & 4 & 5 & 6 \\
\hline 0 & 1 & 2 & 3 & 4 & 5 & 6 \\
\hline 0 & 1 & 2 & 3 & 4 & 5 & 6 \\
\hline 0 & 1 & 2 & 3 & 4 & 5 & 6 \\
\hline 0 & 1 & 2 & 3 & 4 & 5 & 6 \\
\hline 0 & 1 & 2 & 3 & 4 & 5 & 6 \\
\hline 0 & 1 & 2 & 3 & 4 & 5 & 6 \\
\hline 0 & 1 & 2 & 3 & 4 & 5 & 6 \\
\hline 0 & 1 & 2 & 3 & 4 & 5 & 6 \\
\hline 0 & 1 & 2 & 3 & 4 & 5 & 6 \\
\hline 0 & 1 & 2 & 3 & 4 & 5 & 6 \\
\hline 0 & 1 & 2 & 3 & 4 & 5 & 6 \\
\hline 0 & 1 & 2 & 3 & 4 & 5 & 6 \\
\hline 0 & 1 & 2 & 3 & 4 & 5 & 6 \\
\hline 0 & 1 & 2 & 3 & 4 & 5 & 6 \\
\hline 0 & 1 & 2 & 3 & 4 & 5 & 6 \\
\hline & & & & & & $f 22$ \\
\hline & & & & & & 132 \\
\hline physic & I ac & & & & & \\
\hline menta & acti & & & & & \\
\hline
\end{tabular}

percent of normal do you feel?

If not $100 \%$, why?

Please hand form back to examiner 
STEP 3: COGNITIVE SCREENING

Standardised Assessment of Concussion (SAC) ${ }^{4}$

\section{ORIENTATION}

What month is it?

What is the date today?

What is the day of the week?

What year is it?

What time is it right now? (within 1 hour)

Orientation score

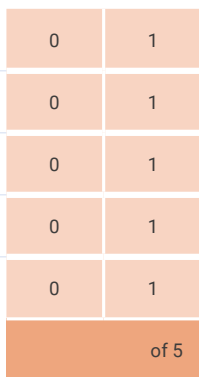

\section{IMMEDIATE MEMORY}

The Immediate Memory component can be completed using the traditional 5-word per trial list or optionally using 10-words per trial to minimise any ceiling effect. All 3 trials must be administered irrespective of the number correct on the first trial. Administer at the rate of one word per second.

Please choose EITHER the 5 or 10 word list groups and circle the specific word list chosen for this test.

I am going to test your memory. I will read you a list of words and when I am done, repeat back as many words as you can remember, in any order. For Trials $2 \& 3$ : I am going to repea the same list again. Repeat back as many words as you can remember in any order, even if you said the word before.

\begin{tabular}{|c|c|c|c|c|c|c|c|c|}
\hline List & \multicolumn{5}{|c|}{ Alternate 5 word lists } & \multicolumn{3}{|c|}{ Score (of 5) } \\
\hline A & Finger & Penny & Blanket & Lemon & Insect & & & \\
\hline B & Candle & Paper & Sugar & Sandwich & Wagon & & & \\
\hline C & Baby & Monkey & Perfume & Sunset & Iron & & & \\
\hline D & Elbow & Apple & Carpet & Saddle & Bubble & & & \\
\hline E & Jacket & Arrow & Pepper & Cotton & Movie & & & \\
\hline $\mathrm{F}$ & Dollar & Honey & Mirror & Saddle & Anchor & & & \\
\hline \multicolumn{6}{|c|}{ Immediate Memory Score } & \multicolumn{3}{|r|}{ of 15} \\
\hline \multicolumn{6}{|c|}{ Time that last trial was completed } & & & \\
\hline
\end{tabular}

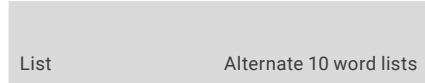

Score (of 10)

Alternate 10 word lists

\begin{tabular}{cccccc|c} 
G & Finger & Penny & Blanket & Lemon & Insect \\
& Candle & Paper & Sugar & Sandwich & Wagon \\
\hline H & Baby & Monkey & Perfume & Sunset & Iron \\
& Elbow & Apple & Carpet & Saddle & Bubble \\
\hline & Jacket & Arrow & Pepper & Cotton & Movie \\
& Dollar & Honey & Mirror & Saddle & Anchor \\
\hline & & & Immediate Memory Score
\end{tabular}

Name:

DOB

Address:

ID number:

Examiner:

Date:

\section{CONCENTRATION}

\section{DIGITS BACKWARDS}

Please circle the Digit list chosen $(A, B, C, D, E, F)$. Administer at the rate of one digit per second reading DOWN the selected column.

I am going to read a string of numbers and when I am done, you repeat them back to $m$ in reverse order of how I read them to you. For example, if I say 7-1-9, you would say 9-1-7.

\begin{tabular}{|c|c|c|c|c|c|}
\hline \multicolumn{6}{|c|}{ Concentration Number Lists (circle one) } \\
\hline List A & List B & List C & & & \\
\hline $4-9-3$ & $5-2-6$ & $1-4-2$ & Y & $\mathrm{N}$ & 0 \\
\hline $6-2-9$ & $4-1-5$ & 6-5-8 & $\mathrm{Y}$ & $\mathrm{N}$ & 1 \\
\hline $3-8-1-4$ & $1-7-9-5$ & $6-8-3-1$ & $\mathrm{Y}$ & $\mathrm{N}$ & 0 \\
\hline $3-2-7-9$ & $4-9-6-8$ & $3-4-8-1$ & $\mathrm{Y}$ & $\mathrm{N}$ & 1 \\
\hline $6-2-9-7-1$ & $4-8-5-2-7$ & $4-9-1-5-3$ & $\mathrm{Y}$ & $\mathrm{N}$ & 0 \\
\hline $1-5-2-8-6$ & $6-1-8-4-3$ & $6-8-2-5-1$ & $\mathrm{Y}$ & $\mathrm{N}$ & 1 \\
\hline $7-1-8-4-6-2$ & $8-3-1-9-6-4$ & $3-7-6-5-1-9$ & $\mathrm{Y}$ & $\mathrm{N}$ & 0 \\
\hline $5-3-9-1-4-8$ & $7-2-4-8-5-6$ & $9-2-6-5-1-4$ & Y & $\mathrm{N}$ & 1 \\
\hline List D & List $\mathrm{E}$ & List $\mathrm{F}$ & & & \\
\hline $7-8-2$ & $3-8-2$ & $2-7-1$ & $\mathrm{Y}$ & $\mathrm{N}$ & 0 \\
\hline $9-2-6$ & $5-1-8$ & $4-7-9$ & $Y$ & $\mathrm{~N}$ & 1 \\
\hline $4-1-8-3$ & $2-7-9-3$ & $1-6-8-3$ & Y & $\mathrm{N}$ & 0 \\
\hline $9-7-2-3$ & $2-1-6-9$ & $3-9-2-4$ & $\mathrm{Y}$ & $\mathrm{N}$ & 1 \\
\hline $1-7-9-2-6$ & $4-1-8-6-9$ & $2-4-7-5-8$ & $Y$ & $\mathrm{~N}$ & 0 \\
\hline $4-1-7-5-2$ & $9-4-1-7-5$ & $8-3-9-6-4$ & Y & $\mathrm{N}$ & 1 \\
\hline $2-6-4-8-1-7$ & $6-9-7-3-8-2$ & $5-8-6-2-4-9$ & $\mathrm{Y}$ & $\mathrm{N}$ & 0 \\
\hline \multirow[t]{2}{*}{$8-4-1-9-3-5$} & $4-2-7-9-3-8$ & $3-1-7-8-2-6$ & $Y$ & $\mathrm{~N}$ & 1 \\
\hline & & Digits Score: & & & of 4 \\
\hline
\end{tabular}

\section{MONTHS IN REVERSE ORDER}

Now tell me the months of the year in reverse order. Start with the last month and go backward. So you'll say December, November. Go ahead.

Dec - Nov - Oct - Sept - Aug - Jul - Jun - May - Apr - Mar - Feb - Jan

Months Score

of 1

Concentration Total Score (Digits + Months)

of 5 


\section{STEP 4: NEUROLOGICAL SCREEN}

See the instruction sheet (page 7) for details of test administration and scoring of the tests.

Can the patient read aloud (e.g. symptom checklist) and follow instructions without difficulty?

Does the patient have a full range of painfree PASSIVE cervical spine movement?

Without moving their head or neck, can the patient look side-to-side and up-and-down without double vision?

Can the patient perform the finger nose

Can the patient perform tandem gait normally?

\begin{tabular}{|c|c|}
\hline Y & N \\
\hline$Y$ & N \\
\hline$Y$ & N \\
\hline$Y$ & N \\
\hline$Y$ & N \\
\hline
\end{tabular}

\section{BALANCE EXAMINATION}

Modified Balance Error Scoring System (mBESS) testing ${ }^{5}$

$\begin{array}{ll}\text { Which foot was tested } & \square \text { Left } \\ \text { (i.e. which is the non-dominant foot) } & \square \text { Right }\end{array}$

Testing surface (hard floor, field, etc.)

Footwear (shoes, barefoot, braces, tape, etc.)

Condition

Errors

Double leg stance

Single leg stance (non-dominant foot)

Tandem stance (non-dominant foot at the back)

Total Errors

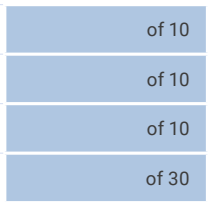

coordination test normally?

Name:

DOB:

Address:

ID number:

Examiner:

Date:

\section{STEP 5: DELAYED RECALL:}

The delayed recall should be performed after 5 minutes have elapsed since the end of the Immediate Recall section. Score 1 pt. for each correct response.

Do you remember that list of words I read a few times earlier? Tell me as many words from the list as you can remember in any order.

Time Started

Please record each word correctly recalled. Total score equals number of words recalled.

STEP 6: DECISION

\begin{tabular}{|c|c|c|c|}
\hline \multirow[b]{2}{*}{ Domain } & \multicolumn{3}{|c|}{ Date \& time of assessment: } \\
\hline & & & \\
\hline \multicolumn{4}{|l|}{$\begin{array}{l}\text { Symptom } \\
\text { number (of 22) }\end{array}$} \\
\hline \multicolumn{4}{|l|}{$\begin{array}{l}\text { Symptom severity } \\
\text { score (of 132) }\end{array}$} \\
\hline \multicolumn{4}{|l|}{ Orientation (of 5) } \\
\hline Immediate memory & $\begin{array}{l}\text { of } 15 \\
\text { of } 30\end{array}$ & $\begin{array}{l}\text { of } 15 \\
\text { of } 30\end{array}$ & $\begin{array}{l}\text { of } 15 \\
\text { of } 30\end{array}$ \\
\hline \multicolumn{4}{|l|}{ Concentration (of 5) } \\
\hline Neuro exam & $\begin{array}{l}\text { Normal } \\
\text { Abnormal }\end{array}$ & $\begin{array}{l}\text { Normal } \\
\text { Abnormal }\end{array}$ & $\begin{array}{c}\text { Normal } \\
\text { Abnormal }\end{array}$ \\
\hline \multicolumn{4}{|l|}{ Balance errors (of 30) } \\
\hline Delayed Recall & $\begin{array}{r}\text { of } 5 \\
\text { of } 10\end{array}$ & $\begin{array}{r}\text { of } 5 \\
\text { of } 10\end{array}$ & $\begin{array}{r}\text { of } 5 \\
\text { of } 10\end{array}$ \\
\hline
\end{tabular}

Date and time of injury:

If the athlete is known to you prior to their injury, are they different from their usual self?

$\square$ Yes $\square$ No $\square$ Unsure $\square$ Not Applicable

(If different, describe why in the clinical notes section)

Concussion Diagnosed?

$\square$ Yes $\square$ No $\square$ Unsure $\square$ Not Applicable

If re-testing, has the athlete improved?

$\square$ Yes $\square$ No $\square$ Unsure $\square$ Not Applicable

I am a physician or licensed healthcare professional and I have personally administered or supervised the administration of this SCAT5.

Signature:

Name:

Title:

Registration number (if applicable):

Date: 


\section{CLINICAL NOTES:}

Name:

DOB:

Address:

ID number:

Examiner:

Date: 


\section{INSTRUCTIONS}

\section{Words in Italics throughout the SCAT5 are the instructions given to the athlete by the clinician}

\section{Symptom Scale}

The time frame for symptoms should be based on the type of test being administered. At baseline it is advantageous to assess how an athlete "typically" feels whereas during the acute/post-acute stage it is best to ask how the athlete feels at the time of testing.

The symptom scale should be completed by the athlete, not by the examiner. In situations where the symptom scale is being completed after exercise, it should be done in a resting state, generally by approximating his/her resting heart rate.

For total number of symptoms, maximum possible is 22 except immediately post injury, if sleep item is omitted, which then creates a maximum of 21.

For Symptom severity score, add all scores in table, maximum possible is $22 \times 6$ $=132$, except immediately post injury if sleep item is omitted, which then creates a maximum of $21 \times 6=126$

\section{Immediate Memory}

The Immediate Memory component can be completed using the traditional 5-word per trial list or, optionally, using 10 -words per trial. The literature suggests that the Immediate Memory has a notable ceiling effect when a 5-word list is used. In settings where this ceiling is prominent, the examiner may wish to make the task more difficult by incorporating two 5 -word groups for a total of 10 words per trial. In this case, the maximum score per trial is 10 with a total trial maximum of 30 .

Choose one of the word lists (either 5 or 10 ). Then perform 3 trials of immediate memory using this list.

Complete all 3 trials regardless of score on previous trials.

"I am going to test your memory. I will read you a list of words and when I am done, repeat back as many words as you can remember, in any order." The words must be read at a rate of one word per second.

Trials $2 \& 3$ MUST be completed regardless of score on trial $1 \& 2$.

Trials $2 \& 3$ :

"I am going to repeat the same list again. Repeat back as many words as you can remember in any order, even if you said the word before."

Score 1 pt. for each correct response. Total score equals sum across all 3 trials. Do NOT inform the athlete that delayed recall will be tested.

\section{Concentration}

\section{Digits backward}

Choose one column of digits from lists A, B, C, D, E or F and administer those digits as follows:

Say: "I am going to read a string of numbers and when I am done, you repeat them back to me in reverse order of how I read them to you. For example, if I say 7-1-9, you would say 9-1-7."

Begin with first 3 digit string.

If correct, circle " $\mathrm{Y}$ " for correct and go to next string length. If incorrect, circle " $\mathrm{N}$ " for the first string length and read trial 2 in the same string length. One point possible for each string length. Stop after incorrect on both trials ( 2 N's) in a string length. The digits should be read at the rate of one per second.

\section{Months in reverse order}

"Now tell me the months of the year in reverse order. Start with the last month and go backward. So you'll say December, November... Go ahead"

1 pt. for entire sequence correct

\section{Delayed Recall}

The delayed recall should be performed after 5 minutes have elapsed since the end of the Immediate Recall section.

"Do you remember that list of words I read a few times earlier? Tell me as many words from the list as you can remember in any order."

Score 1 pt. for each correct response

\section{Modified Balance Error Scoring System (mBESS) ${ }^{5}$ testing}

This balance testing is based on a modified version of the Balance Error Scoring System $(B E S S)^{5}$. A timing device is required for this testing.

Each of 20-second trial/stance is scored by counting the number of errors. The examiner will begin counting errors only after the athlete has assumed the proper start position. The modified BESS is calculated by adding one error point for each error during the three 20 -second tests. The maximum number of errors for any single condition is 10 . If the athlete commits multiple errors simultaneously, only one error is recorded but the athlete should quickly return to the testing position, and counting should resume once the athlete is set. Athletes that are unable to maintain the testing procedure for a minimum of five seconds at the start are assigned the highest possible score, ten, for that testing condition.

OPTION: For further assessment, the same 3 stances can be performed on a surface of medium density foam (e.g., approximately $50 \mathrm{~cm} \times 40 \mathrm{~cm} \times 6 \mathrm{~cm}$ ).

\section{Balance testing - types of errors}

\begin{tabular}{|c|c|c|}
\hline 1. Hands lifted off & 3. Step, stumble, or fall & 5. Lifting forefoot or heel \\
\hline 2. Opening eyes & $\begin{array}{l}\text { 4. Moving hip into }>30 \\
\text { degrees abduction }\end{array}$ & $\begin{array}{l}\text { 6. Remaining out of test } \\
\text { position }>5 \mathrm{sec}\end{array}$ \\
\hline
\end{tabular}

"I am now going to test your balance. Please take your shoes off (if applicable), roll up your pant legs above ankle (if applicable), and remove any ankle taping (if applicable). This test will consist of three twenty second tests with different stances."

(a) Double leg stance

"The first stance is standing with your feet together with your hands on your hips and with your eyes closed. You should try to maintain stability in that position for 20 seconds. I will be counting the number of times you move out of this position. I will start timing when you are set and have closed your eyes."

(b) Single leg stance:

"If you were to kick a ball, which foot would you use? [This will be the dominant foot] Now stand on your non-dominant foot. The dominant leg should be held in approximately 30 degrees of hip flexion and 45 degrees of knee flexion. Again, you should try to maintain stability for 20 seconds with your hands on your hips and your eyes closed. I will be counting the number of times you move out of this position. If you stumble out of this position, open your eyes and return to the start position and continue balancing. I will start timing when you are set and have closed your eyes."

(c) Tandem stance

"Now stand heel-to-toe with your non-dominant foot in back. Your weight should be evenly distributed across both feet. Again, you should try to maintain stability for 20 seconds with your hands on your hips and your eyes closed. I will be counting the number of times you move out of this position. If you stumble out of this position, open your eyes and return to the start position and continue balancing. I will start timing when you are set and have closed your eyes."

\section{Tandem Gait}

Participants are instructed to stand with their feet together behind a starting line (the test is best done with footwear removed). Then, they walk in a forward direction as quickly and as accurately as possible along a $38 \mathrm{~mm}$ wide (sports tape), 3 metre line with an alternate foot heel-to-toe gait ensuring that they approximate their heel and toe on each step. Once they cross the end of the $3 \mathrm{~m}$ line, they turn 180 degrees and return to the starting point using the same gait. Athletes fail the test if they step off the line, have a separation between their heel and toe, or if they touch or grab the examiner or an object.

\section{Finger to Nose}

"I am going to test your coordination now. Please sit comfortably on the chair with your eyes open and your arm (either right or left) outstretched (shoulder flexed to 90 degrees and elbow and fingers extended), pointing in front of you. When I give a start signal, I would like you to perform five successive finger to nose repetitions using your index finger to touch the tip of the nose, and then return to the starting position, as quickly and as accurately as possible."

\section{References}

1. McCrory et al. Consensus Statement On Concussion In Sport - The 5th International Conference On Concussion In Sport Held In Berlin, October 2016. British Journal of Sports Medicine 2017 (available at www.bjsm.bmj.com)

2. Maddocks, DL; Dicker, GD; Saling, MM. The assessment of orientation following concussion in athletes. Clinical Journal of Sport Medicine 1995; 5: 32-33

3. Jennett, B., Bond, M. Assessment of outcome after severe brain damage: a practical scale. Lancet 1975; i: 480-484

4. McCrea M. Standardized mental status testing of acute concussion. Clinical Journal of Sport Medicine. 2001; 11: 176-181

5. Guskiewicz KM. Assessment of postural stability following sport-related concussion. Current Sports Medicine Reports. 2003; 2: 24-30 


\section{CONCUSSION INFORMATION}

Any athlete suspected of having a concussion should be removed from play and seek medical evaluation.

\section{Signs to watch for}

Problems could arise over the first $24-48$ hours. The athlete should not be left alone and must go to a hospital at once if they experience:

$\begin{array}{lll}\begin{array}{l}\text { Worsening } \\ \text { headache }\end{array} & \text { Repeated vomiting } & \begin{array}{l}\text { Weakness or } \\ \text { numbness in } \\ \text { arms or legs }\end{array} \\ \begin{array}{l}\text { Drowsiness or } \\ \text { inability to be } \\ \text { awakened }\end{array} & \begin{array}{l}\text { or confusion } \\ \text { or irritable }\end{array} & \begin{array}{l}\text { Unsteadiness } \\ \text { on their feet. }\end{array} \\ \begin{array}{l}\text { Inability to } \\ \text { recognize people } \\ \text { or places }\end{array} & \begin{array}{l}\text { Seizures (arms } \\ \text { and legs jerk } \\ \text { uncontrollably) }\end{array} & \text { - Slurred speech }\end{array}$

Consult your physician or licensed healthcare professional after a suspected concussion. Remember, it is better to be safe.

\section{Rest \& Rehabilitation}

After a concussion, the athlete should have physical rest and relative cognitive rest for a few days to allow their symptoms to improve. In most cases, after no more than a few days of rest, the athlete should gradually increase their daily activity level as long as their symptoms do not worsen. Once the athlete is able to complete their usual daily activities without concussion-related symptoms, the second step of the return to play/sport progression can be started. The athlete should not return to play/sport until their concussion-related symptoms have resolved and the athlete has successfully returned to full school/learning activities.

When returning to play/sport, the athlete should follow a stepwise medically managed exercise progression, with increasing amounts of exercise. For example:

\section{Graduated Return to Sport Strategy}

\begin{tabular}{|c|c|c|}
\hline Exercise step & $\begin{array}{l}\text { Functional exercise } \\
\text { at each step }\end{array}$ & Goal of each step \\
\hline $\begin{array}{l}\text { 1. Symptom- } \\
\text { limited activity }\end{array}$ & $\begin{array}{l}\text { Daily activities that do } \\
\text { not provoke symptoms. }\end{array}$ & $\begin{array}{l}\text { Gradual reintroduc- } \\
\text { tion of work/school } \\
\text { activities. }\end{array}$ \\
\hline $\begin{array}{l}\text { 2. Light aerobic } \\
\text { exercise }\end{array}$ & $\begin{array}{l}\text { Walking or stationary } \\
\text { cycling at slow to medium } \\
\text { pace. No resistance } \\
\text { training. }\end{array}$ & Increase heart rate. \\
\hline $\begin{array}{l}\text { 3. Sport-specific } \\
\text { exercise }\end{array}$ & $\begin{array}{l}\text { Running or skating drills. } \\
\text { No head impact activities. }\end{array}$ & Add movement. \\
\hline $\begin{array}{l}\text { 4. Non-contact } \\
\text { training drills }\end{array}$ & $\begin{array}{l}\text { Harder training drills, e.g., } \\
\text { passing drills. May start } \\
\text { progressive resistance } \\
\text { training. }\end{array}$ & $\begin{array}{l}\text { Exercise, coor- } \\
\text { dination, and } \\
\text { increased thinking. }\end{array}$ \\
\hline $\begin{array}{l}\text { 5. Full contact } \\
\text { practice }\end{array}$ & $\begin{array}{l}\text { Following medical clear- } \\
\text { ance, participate in normal } \\
\text { training activities. }\end{array}$ & $\begin{array}{l}\text { Restore confi- } \\
\text { dence and assess } \\
\text { functional skills by } \\
\text { coaching staff. }\end{array}$ \\
\hline $\begin{array}{l}\text { 6. Return to } \\
\text { play/sport }\end{array}$ & Normal game play. & \\
\hline
\end{tabular}

In this example, it would be typical to have 24 hours (or longer) for each step of the progression. If any symptoms worsen while exercising, the athlete should go back to the previous step. Resistance training should be added only in the later stages (Stage 3 or 4 at the earliest).

Written clearance should be provided by a healthcare professional before return to play/sport as directed by local laws and regulations.

\section{Graduated Return to School Strategy}

Concussion may affect the ability to learn at school. The athlete may need to miss a few days of school after a concussion. When going back to school, some athletes may need to go back gradually and may need to have some changes made to their schedule so that concussion symptoms do not get worse. If a particular activity makes symptoms worse, then the athlete should stop that activity and rest until symptoms get better. To make sure that the athlete can get back to school without problems, it is important that the healthcare provider, parents, caregivers and teachers talk to each other so that everyone knows what the plan is for the athlete to go back to school.

Note: If mental activity does not cause any symptoms, the athlete may be able to skip step 2 and return to school part-time before doing school activities at home first.

\begin{tabular}{|c|c|c|}
\hline Mental Activity & Activity at each step & $\begin{array}{l}\text { Goal of } \\
\text { each step }\end{array}$ \\
\hline $\begin{array}{l}\text { 1. Daily activities } \\
\text { that do } \\
\text { not give } \\
\text { the athlete } \\
\text { symptoms }\end{array}$ & $\begin{array}{l}\text { Typical activities that the athlete } \\
\text { does during the day as long as } \\
\text { they do not increase symptoms } \\
\text { (e.g. reading, texting, screen } \\
\text { time). Start with } 5-15 \text { minutes at } \\
\text { a time and gradually build up. }\end{array}$ & $\begin{array}{l}\text { Gradual } \\
\text { return to } \\
\text { typical } \\
\text { activities. }\end{array}$ \\
\hline $\begin{array}{l}\text { 2. School } \\
\text { activities }\end{array}$ & $\begin{array}{l}\text { Homework, reading or other } \\
\text { cognitive activities outside of } \\
\text { the classroom. }\end{array}$ & $\begin{array}{l}\text { Increase } \\
\text { tolerance } \\
\text { to cognitive } \\
\text { work. }\end{array}$ \\
\hline $\begin{array}{l}\text { 3. Return to } \\
\text { school } \\
\text { part-time }\end{array}$ & $\begin{array}{l}\text { Gradual introduction of school- } \\
\text { work. May need to start with } \\
\text { a partial school day or with } \\
\text { increased breaks during the day. }\end{array}$ & $\begin{array}{l}\text { Increase } \\
\text { academic } \\
\text { activities. }\end{array}$ \\
\hline $\begin{array}{l}\text { 4. Return to } \\
\text { school } \\
\text { full-time }\end{array}$ & $\begin{array}{l}\text { Gradually progress school } \\
\text { activities until a full day can be } \\
\text { tolerated. }\end{array}$ & $\begin{array}{l}\text { Return to full } \\
\text { academic } \\
\text { activities and } \\
\text { catch up on } \\
\text { missed work. }\end{array}$ \\
\hline
\end{tabular}

If the athlete continues to have symptoms with mental activity, some other accomodations that can help with return to school may include:

- Starting school later, only
going for half days, or going
only to certain classes
- More time to finish
assignments/tests
- Quiet room to finish
assignments/tests
- Not going to noisy areas
like the cafeteria, assembly
halls, sporting events, music
class, shop class, etc.

The athlete should not go back to sports until they are back to school/ learning, without symptoms getting significantly worse and no longer needing any changes to their schedule.

\footnotetext{
- Taking lots of breaks during class, homework, tests

- No more than one exam/day

- Shorter assignments

- Repetition/memory cues

- Use of a student helper/tutor

- Reassurance from teachers that the child will be supported while getting better
} 